University of Nebraska - Lincoln

DigitalCommons@University of Nebraska - Lincoln

\title{
Catfish Population Characteristics among River Segments with Altered Fluvial Geomorphic Conditions in the Missouri River, Nebraska, USA
}

\author{
Martin J. Hamel \\ University of Georgia, mjh50785@uga.edu \\ Jonathan J. Spurgeon \\ University of Arkansas at Pine Bluff \\ Mark A. Pegg \\ University of Nebraska-Lincoln, mpegg2@unl.edu
}

Follow this and additional works at: https://digitalcommons.unl.edu/natrespapers

Part of the Aquaculture and Fisheries Commons, Natural Resources and Conservation Commons, Natural Resources Management and Policy Commons, and the Other Environmental Sciences Commons

Hamel, Martin J.; Spurgeon, Jonathan J.; and Pegg, Mark A., "Catfish Population Characteristics among River Segments with Altered Fluvial Geomorphic Conditions in the Missouri River, Nebraska, USA" (2020). Papers in Natural Resources. 1302.

https://digitalcommons.unl.edu/natrespapers/1302

This Article is brought to you for free and open access by the Natural Resources, School of at DigitalCommons@University of Nebraska - Lincoln. It has been accepted for inclusion in Papers in Natural Resources by an authorized administrator of DigitalCommons@University of Nebraska - Lincoln. 


\title{
Catfish Population Characteristics among River Segments with Altered Fluvial Geomorphic Conditions in the Missouri River, Nebraska, USA
}

\author{
Martin J. Hamel, ${ }^{1}$ Jonathan J. Spurgeon, ${ }^{2}$ and Mark A. Pegg ${ }^{3}$
}

1. Warnell School of Forestry and Natural Resources, University of Georgia, 180 East Green Street, Athens, Georgia, USA

2. University of Arkansas at Pine Bluff, 1200 North University, Pine Bluff, Arkansas, USA

3. University of Nebraska-Lincoln, 3310 Holdrege Street, Lincoln, Nebraska 68583, USA

Corresponding author - Martin J. Hamel, Warnell School of Forestry and Natural Resources, University of Georgia, 180 E. Green St., Athens, GA 30602, USA, email hamel@uga.edu

\begin{abstract}
Alteration of river systems around the world has created novel environments that have been fragmented, homogenized, or transformed from their natural state, thus posing challenges for understanding how fish populations function. The Missouri River has undergone significant alteration through reservoir construction and channelization. Channel Catfish Ictalurus punctatus and Flathead Catfish Pylodictis olivaris both reside in various fragmented sections of the river, and there is a substantial gap in knowledge of how catfishes synchronously function in this modified system. From 2009 to 2018, we assessed catfishes with baited hoop nets and low-frequency electrofishing among four different areas: upper and lower unchannelized segments and upper and lower channelized segments. Differences in population demographics and dynamics occurred for both species among segments. Both the highest and lowest relative abundances for Channel Catfish occurred in channelized segments, and Flathead Catfish relative abundance was lowest in both unchannelized segments. Subadult growth rates for both catfish species were greater in channelized segments. Channel Catfish mortality was highest in channelized segments, which was consistent with the maximum ages found in channelized (age 9) versus unchannelized (age 15) segments. High-flow events in 2010 and 2011 led to an increase in recruitment, but populations declined in subsequent years. This long-term
\end{abstract}


assessment revealed spatial and temporal differences in population dynamics among varying levels of anthropogenic alteration. Our study illustrates how river modification and extreme climatological events may impact and structure catfish populations. These data provide a basis for assessing catfish throughout the Missouri River system and offer insight into how catfish populations in other altered large-river systems might function.

Large-river systems around the world have undergone fragmentation, alteration in physical habitat, and hydrologic changes, with implications for the population dynamics of multiple fish species (Dynesius and Nilsson 1994; Bunn and Arthington 2002; McManamay and Frimpong 2015). River modifications can cause both positive and negative impacts to species depending on life history attributes. Generally, opportunistic strategists (sensu Winemiller and Rose 1992) and species that can survive and reproduce under broad habitat types may be favored under modified conditions (Mims and Olden 2013). However, fish population responses to river modification will largely be determined by the type of anthropogenic impact. For example, a homogenized flow regime-modified by dams and their releases - may benefit populations of fishes characterized by an equilibrium life history strategy (McManamay and Frimpong 2015). Predicting fish population response and understanding drivers that might lead to change in fish populations through space and time is of great interest to fish managers. Assessments of fish populations in large-river systems, however, are challenging because sampling efficiency can vary both spatially and temporally (Pritt et al. 2014). Thus, long-term monitoring may afford evaluations of largeriver fish populations and the impacts of environmental conditions, including anthropogenic alteration.

The Missouri River is the longest river in the United States, stretching nearly 4,400 km from western Montana to its confluence with the Mississippi River in Missouri. The Missouri River underwent a widespread transformation beginning in the early 1930s, when a series of five reservoirs was constructed along the river's length in the upper Great Plains. Below the lowermost reservoir, the remaining 1,211 km of river were channelized for navigation. Revetted banks and channel control structures were also installed in the lower river to maintain a self-scouring, 2.7-m-deep channel. Since channelization, the lower Missouri River has been dramatically changed into a narrow and swift-flowing river (Funk and Robinson 1974). The longitudinal changes in habitat along the Missouri River have been implicated in abundance declines and distribution restrictions of multiple native species (Galat et al. 2005).

The Channel Catfish Ictalurus punctatus and Flathead Catfish Pylodictis olivaris are two catfish species commonly found in North American river systems, including throughout the Missouri River basin. Both Channel Catfish and Flathead Catfish are encountered throughout areas of the lower Missouri River, although less attention has been historically focused on understanding the population dynamics of these species. As such, there exists a substantial gap in our understanding of how catfishes synchronously function in such a heavily modified river system. For instance, little information exists regarding differences in large-scale patterns of population responses (i.e., relative abundance, condition, and size structure) to changes in habitat conditions. An understanding of the large-scale species segregation and population patterns of the two species would provide valuable information for 
prioritizing species-specific management strategies at broad spatial scales. Therefore, we developed a standardized, long-term sampling approach to assess trends in catfish populations within a lower Missouri River reach $(552 \mathrm{~km})$ that was subjected to different physical habitat modifications. Sampling was stratified across four Missouri River segments that have been subject to varying types of anthropogenic impacts. Our objective was to assess dynamic rate functions of Channel Catfish and Flathead Catfish populations within the four river segments and relate findings to the broad-scale differences among river segments.

\section{Methods}

\section{Study area}

Our sampling regime was split among four sampling segments that each contained unique characteristics (Figure 1). The upper unchannelized segment extended from the headwaters of Lewis and Clark Lake (river kilometer [rkm] 1,352 measured from the mouth of the Missouri River) in Nebraska to Fort Randall Dam (rkm 1,419) in South Dakota. This segment did not contain channel control structures (i.e., revetted banks and wing dikes) and included a large tributary (the Niobrara River) inflow near the midpoint of the segment. The lower unchannelized segment extended from the confluence of the Big Sioux River upstream to Gavins Point Dam ( $\mathrm{rkm} 1,308)$ and consisted of a 95-km stretch of river that contained no channel control structures or wing dikes. Although this segment resembled historical physical conditions (e.g., braided channel and exposed sand bars), flow modifications have resulted in a $77 \%$ reduction in the number and area of historic side channels (Yager et al. 2013). Flow and water chemistry were also altered because of deepwater releases from Gavins Point Dam.

The upper channelized segment extended from the confluence of the Platte River (rkm 960) upstream to the Big Sioux River confluence (rkm 1,184). This reach had limestone rock-lined banks with channel control structures on the inside bend. Collectively, this segment has less annual discharge and reduced turbidity (Hesse and Sheets 1993) relative to the lower channelized segment. The lower channelized segment extended from the KansasNebraska border (rkm 794) to the confluence of the Platte River (rkm 960). This segment was characterized by uniform channel morphology, bank lining with large limestone rock, and rock dike structures that controlled flow on the inside bends. The Platte River is a major tributary to the Missouri River and significantly increases discharge and turbidity, thereby impacting the Missouri River downstream. 


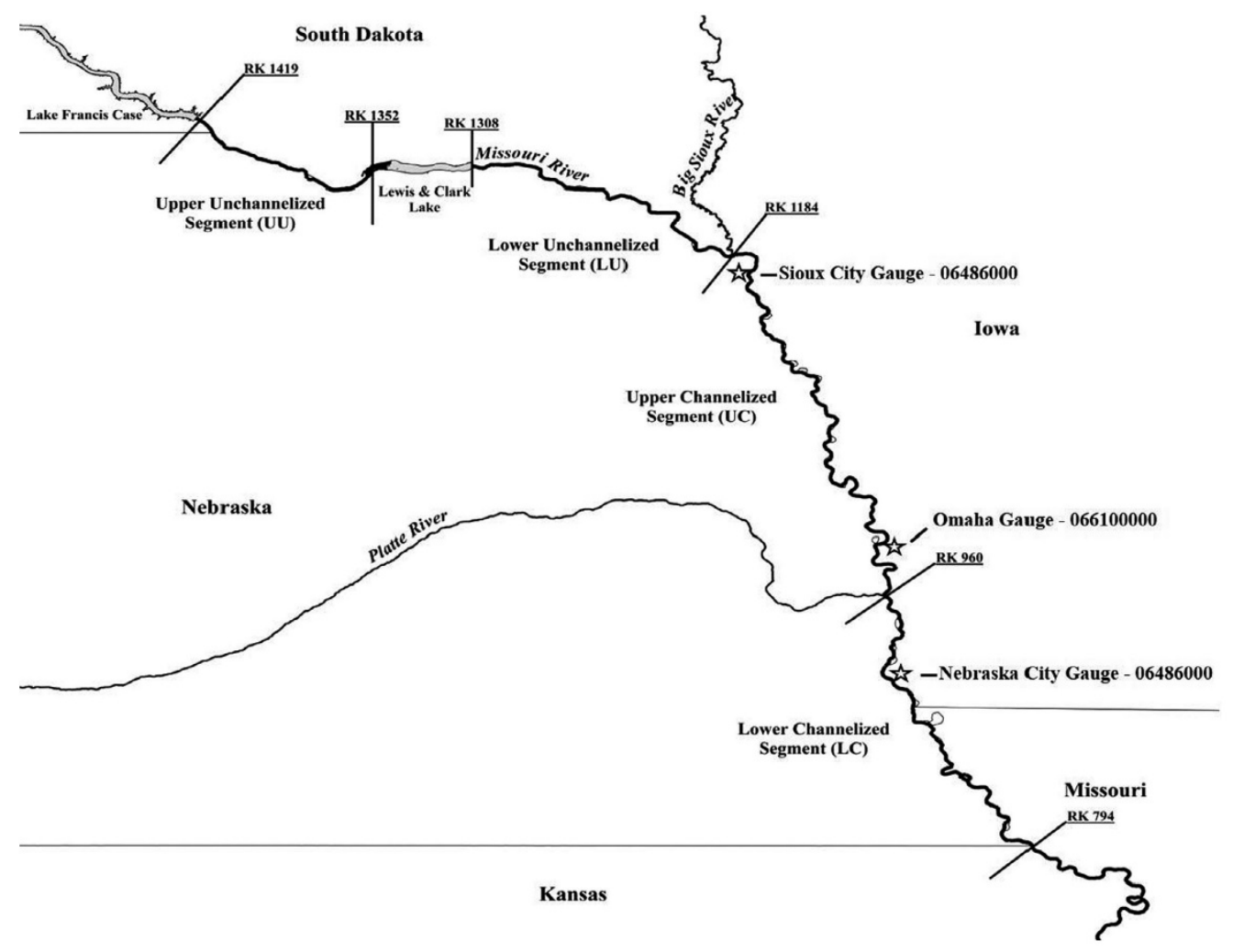

Figure 1. Study area map, showing the boundaries and U.S. Geological Survey water gauging stations for each sampling segment of the Missouri River (RK = river kilometer).

\section{Fish sampling}

We sampled catfish by using hoop nets and low-frequency electrofishing during the summer months (July-September). We deployed both gears on separate occasions in randomly selected bends ( $n=6$ bends selected annually) within each of the four river segments (Figure 1). We used 0.6-m-diameter, 7-hoop, 25-mm-mesh hoop nets with throats on the second and fourth hoops. We baited each net with approximately $1 \mathrm{~kg}$ of scrap cheese placed in a nylon-mesh bag tied in the cod end of the net. We set hoop nets in two bends each day, with 10 nets/bend. Within each bend, we used five nets on the inside bend and five nets on the outside bend. Nets were anchored on the open end with concrete anchors, and a hook was attached to the cod end, which was then secured to bankline structures (e.g., tree limb, rock, etc.). We placed nets parallel to shore in at least $0.6 \mathrm{~m}$ of water with enough current to keep the net from collapsing. Total net set time was approximately $24 \mathrm{~h}$, and effort was calculated as the number of fish collected per hoop-net-night.

Electrofishing occurred on the same bends as hoop nets after at least $7 \mathrm{~d}$ had passed since prior sampling. We staggered electrofishing samples $(n=8)$ at each bend so that four runs occurred on the inside bend bank and four runs occurred on the outside bend bank. The length of each electrofishing run was one-eighth the length of the river bend. The mean distance $\pm \mathrm{SE}$ of each downstream electrofishing run was $634.6 \pm 1.5 \mathrm{~m}(557 \pm 1.4 \mathrm{~s}$ of 
operation). We used a 15-Hz, 3-4-A, pulsed-DC electric field produced by a boat-mounted generator and a Smith-Root Model 5.0 generator-powered pulsator. The crew consisted of one driver and at least one netter for both an electrofishing boat and a chase boat. The chase boat was positioned approximately $20 \mathrm{~m}$ downstream of the electrofishing boat to capture fish that surfaced too far from the electrofishing boat.We measured individuals for $\mathrm{TL}$ (nearest $\mathrm{mm}$ ) and weight (nearest g). Sampling effort was calculated as the number of fish collected per minute of electrofishing.

\section{Age and growth procedures}

We removed the left pectoral spine from five catfish per 10-mm length-group ( $<800 \mathrm{~mm}$ ) for age and growth analyses. We did not remove pectoral spines from individuals larger than $800 \mathrm{~mm}$ to reduce potential mortality from the large wound created. Sections of pectoral spines have been shown to provide adequate precision among readers for fish younger than age 4 (Buckmeier et al. 2002). We cleaned pectoral spines in the lab and sectioned each using a Buehler Iso-Met saw. We prepared spines using methods from Koch and Quist (2007), with the spine being embedded in epoxy to reduce damage and facilitate manipulation during sectioning. We mounted spine cross-sections on glass slides and photographed them by using a high-resolution digital camera. We imported the digital images into image analysis software for manual aging. Two viewers independently assigned ages, and a tandem viewing of the spine was used to reach agreement when a discrepancy occurred. Age information was not collected for Flathead Catfish in the lower channelized segment during 2018.

\section{Data analyses}

Hydrologic information was summarized for each segment based on data from the nearest U.S. Geological Survey (USGS) water gauging station. Mean annual discharge was not available for the upper unchannelized segment, and additional water quality metrics (e.g., temperature) were not available for all gauges or for the duration of the study. We estimated relative abundance (CPUE), size structure, age structure, relative weight $\left(W_{r}\right)$, and mortality among segments for both Channel Catfish and Flathead Catfish each year between 2009 and 2018, except 2011, during which extensive, prolonged flooding occurred. For these analyses, we restricted CPUE estimates to hoop nets for Channel Catfish and electrofishing for Flathead Catfish, as these gears provide the most consistency in catch rates for each species (Vokoun and Rabeni 2001; Buckmeier and Schlechte 2009; Bodine et al. 2013). Data for each species did not resemble a normal distribution; therefore, we used a nonparametric Kruskal-Wallis test to compare CPUE among segments and Dunn's test to conduct pairwise comparisons. Mean annual growth increment at age 3 among segments was analyzed using a single-factor ANOVA. Age 3 was chosen because these fish were fully recruited to the sampling gears but were not yet sexually mature. Somatic growth during this time would not be influenced by reproductive energy requirements, providing a means by which to compare absolute growth in response to environmental conditions.

We compared mean $W_{r}$ among segments by using a single-factor ANOVA. We used Tukey's adjustment to maintain an overall $\alpha$ of 0.05 for multiple comparisons among 
segments following the procedures described by Pope and Kruse (2007). Weighted catchcurve regression (Maceina and Bettoli 1998) was used to estimate instantaneous mortality $(Z)$ and annual mortality $(A)$ in each segment. The catch-curve analysis included age-3 and older Flathead Catfish and Channel Catfish. We compared differences in estimated mortality among segments by using a single-factor ANOVA. Insight into recruitment trends was assessed by examining the total catch of age-2 fish and back-calculating to the year of hatching (i.e., year-class). The total number of fish per year-class was plotted for each segment in relation to mean annual discharge $\left(\mathrm{m}^{3} / \mathrm{s}\right)$ near the midpoint of the entire 552-km sample area (USGS gauge 06610000 [Omaha, Nebraska]; Figure 1). All analyses were performed in program $\mathrm{R}$ (R Core Team 2019) using the package FSA (Ogle et al. 2020).

\section{Results}

Mean annual discharge $\left(\mathrm{m}^{3} / \mathrm{s}\right)$ varied from 2009 to 2018 (Figure 2). High-water events occurred in 2010, 2011, and 2018. Mean annual discharge in 2011 was the highest ever recorded and resulted in sustained flooding for several months. The hydrographs for each gauging station generally mimicked each other; however, distinction in annual flow patterns among the gauging stations occurred during some years. Tributary inputs within respective segments were largely responsible for these differences. For example, the Platte River (USGS gauge 06805500 [Louisville, Nebraska]) was in the top 75th percentile in historical mean annual flow statistics, thereby increasing mean annual discharge in the lower channelized segment but not in the remaining segments.

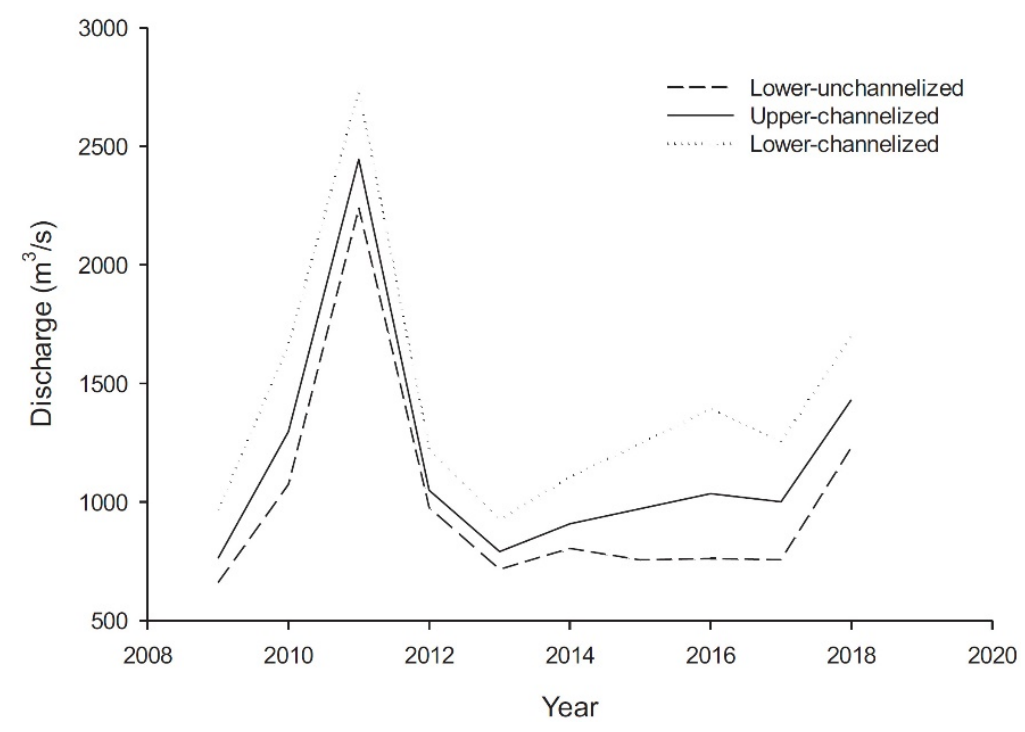

Figure 2. Mean annual discharge $\left(\mathrm{m}^{3} / \mathrm{s}\right)$ reported from the nearest U.S. Geological Survey water gauge in each sampling segment (lower unchannelized: Sioux City, Iowa, gauge 06486000; upper channelized: Omaha, Nebraska, gauge 06610000; lower channelized: Nebraska City, Nebraska, gauge 06807000). Discharge information was not available for the upper unchannelized segment. 


\section{Channel Catfish}

Channel Catfish $(N=6,757)$ relative abundance differed among the river segments when all years were combined $(\chi 2=50.90, \mathrm{df}=3, P<0.001)$. The greatest $C$ hannel Catfish relative abundance occurred in the upper channelized segment $(\mathrm{CPUE}$ [mean $\pm \mathrm{SE}$ ] $=3.74 \pm 0.39$ fish/hoop-net-night; $P<0.001)$, and the lowest relative abundance of this species occurred in the lower channelized segment (CPUE $=1.16 \pm 0.14$ fish/hoop-net-night; $P<0.001$ ). Throughout all segments, relative abundance was generally higher in years prior to 2014 (Figure 3). Size structure generally increased from downstream to upstream (Figure 4). Larger, older fish were found in the unchannelized segments of the Missouri River (although no individuals $>800 \mathrm{~mm}$ were captured), and smaller, younger fish were present in the channelized segments (Figure 4; Table 1). Ages of Channel Catfish ranged from 1 to 15 years in the upper unchannelized segment and from 1 to 9 years in the lower channelized segment. Fish in the lower channelized segment displayed a greater growth increment at age 3 than fish in any other segment $\left(F_{4,34}=5.753, P=0.001\right.$; Table 1$)$. 

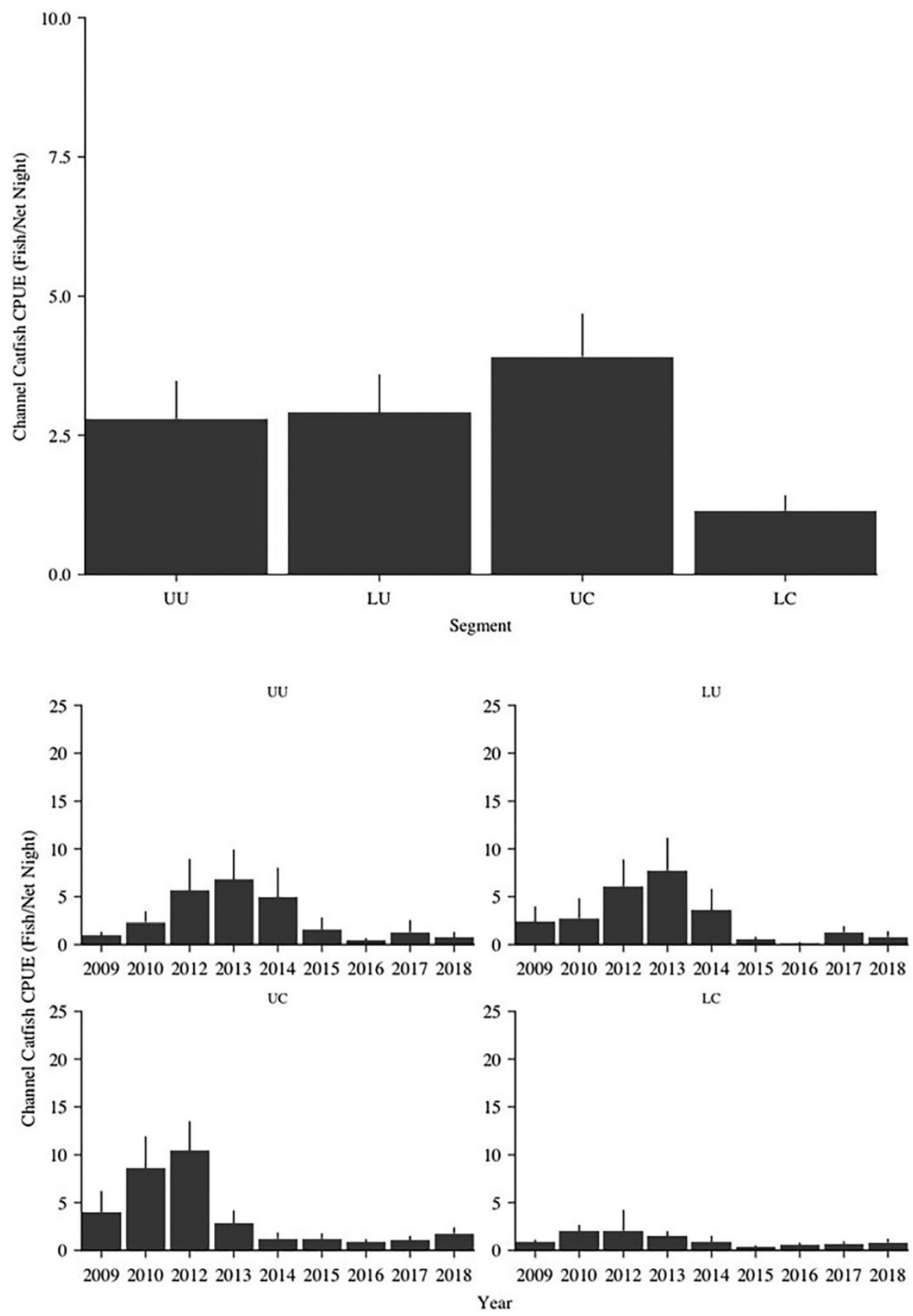

Figure 3. Channel Catfish mean CPUE (fish/hoop-net-night; with 95\% confidence interval) calculated from standardized assessments conducted during 2009-2018 in four segments of the Missouri River: upper unchannelized (UU), lower unchannelized (LU), upper channelized (UC), and lower channelized (LC). Top panel shows all years combined for each segment; bottom panel shows annual comparisons among segments. 

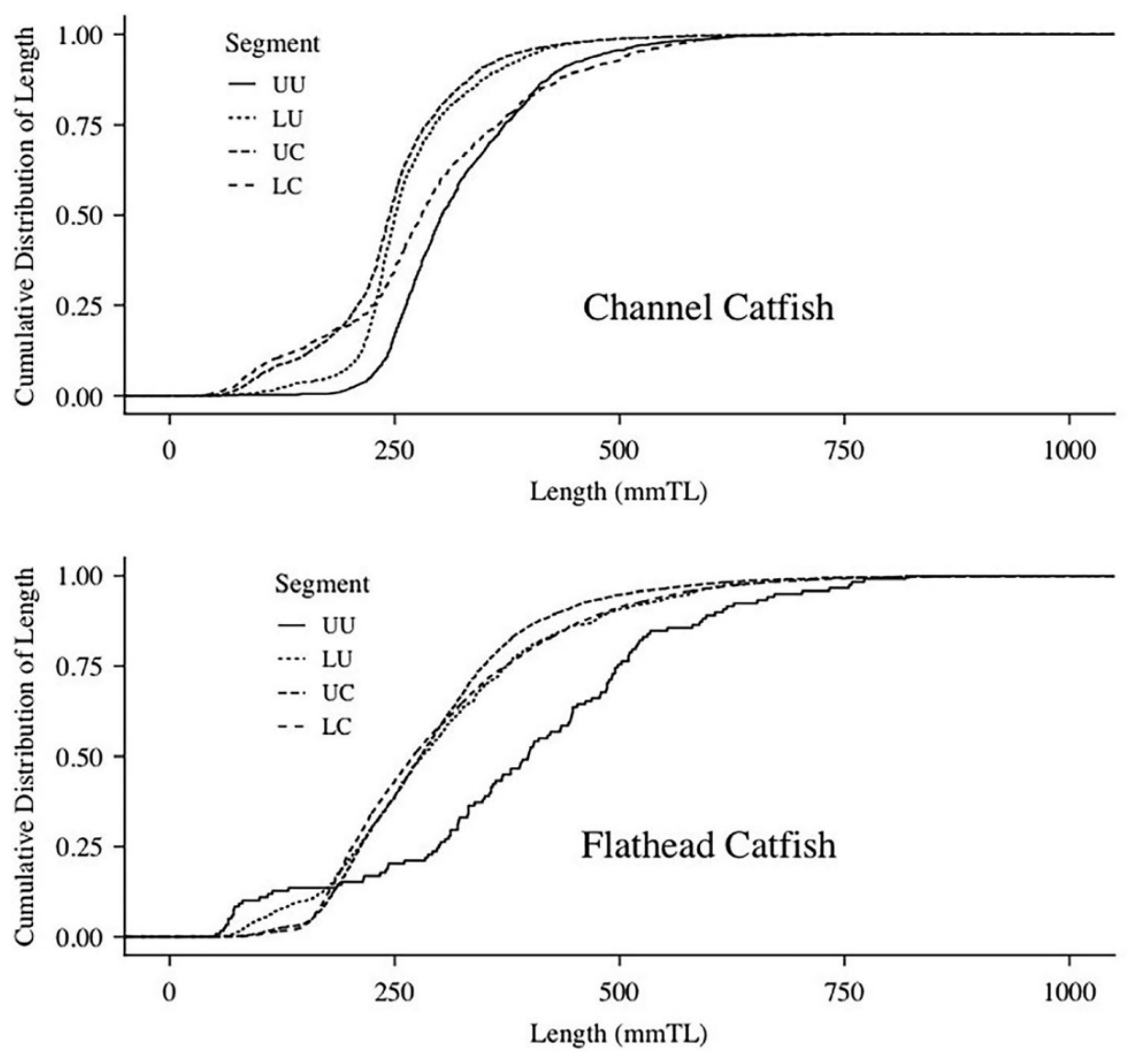

Figure 4. Cumulative length frequency histograms for Channel Catfish (top panel) captured with hoop nets and Flathead Catfish (bottom panel) captured with electrofishing for all years combined (2009-2018) in four segments of the Missouri River: upper unchannelized (UU), lower unchannelized (LU), upper channelized (UC), and lower channelized (LC). 
Table 1. Summary of Channel Catfish and Flathead Catfish population parameters (mean, with SE in parentheses; $W_{r}=$ relative weight) calculated from standardized assessments conducted during 20092018 in four segments of the Missouri River: upper unchannelized (UU), lower unchannelized (LU), upper channelized (UC), and lower channelized (LC). Channel Catfish CPUE is reported from hoopnet catch (fish/hoop-net-night); Flathead Catfish CPUE is reported from low-frequency electrofishing (fish/min). Maximum age of Flathead Catfish is not given because of age structure removal limitations described in Methods (age structures were collected only from fish $<800 \mathrm{~mm} \mathrm{TL}$ ).

\begin{tabular}{lcccc}
\hline Variable & UU & LU & UC & LC \\
\hline & \multicolumn{3}{c}{ Channel Catfish } \\
Relative abundance (CPUE) & $2.92(0.35)$ & $2.85(0.35)$ & $3.74(0.39)$ & $1.16(0.14)$ \\
Maximum age (years) & 15 & 12 & 13 & 9 \\
Condition $\left(W_{r}\right)$ & $85(0.31)$ & $86(0.32)$ & $99(0.32)$ & $101(0.60)$ \\
Growth at age 3 (mm/year) & $33.60(16.13)$ & $57.40(9.76)$ & $55.60(9.85)$ & $74.20(21.60)$ \\
Total annual mortality (\%) & $37(8)$ & $46(6)$ & $56(3)$ & $51(12)$ \\
& & Flathead Catfish & \\
Relative abundance (CPUE) & $0.09(0.01)$ & $0.66(0.06)$ & $1.53(0.07)$ & $2.16(0.10)$ \\
Maximum age (years) & - & - & - & - \\
Condition $\left(W_{r}\right)$ & $91(1.05)$ & $99(12.64)$ & $100(0.20)$ & $95(0.16)$ \\
Growth at age 3 (mm/year) & $23.70(30.04)$ & $71.80(20.49)$ & $67.20(13.79)$ & $66.90(9.39)$ \\
Total annual mortality $(\%)$ & $62(20)$ & $43(6)$ & $51(3)$ & $53(9)$ \\
\hline
\end{tabular}

There was a significant difference in mean $W_{r}$ among segments for Channel Catfish $\left(F_{3,32}\right.$ $=3.287, P=0.0332)$. Mean $W_{r}$ was similar between the lower and upper channelized segments (lower: $W_{r}$ [mean \pm SE] $=101 \pm 0.60$; upper: $W_{r}=99 \pm 0.32$ ) and between the lower and upper unchannelized segments (lower: $W_{r}=86 \pm 0.32$; upper: $W_{r}=85 \pm 0.31$; Figure 5). Total $Z$ differed among river segments for Channel Catfish $\left(F_{3,30}=7.10, P<0.001\right)$. Total $A$ was $51 \%$ in the lower channelized segment, $56 \%$ in the upper channelized segment, $46 \%$ in the lower unchannelized segment, and $37 \%$ in the upper unchannelized segment across years (Table 1). Recruitment was highest in 2010 after several years of relatively low mean annual discharge (Figure 6). The number of recruits captured from the 2011 year-class was lower than that captured from the 2010 year-class but was generally higher than that in most other years. After 2011, recruitment declined in all segments and remained low throughout the remainder of the study (Figure 6). 


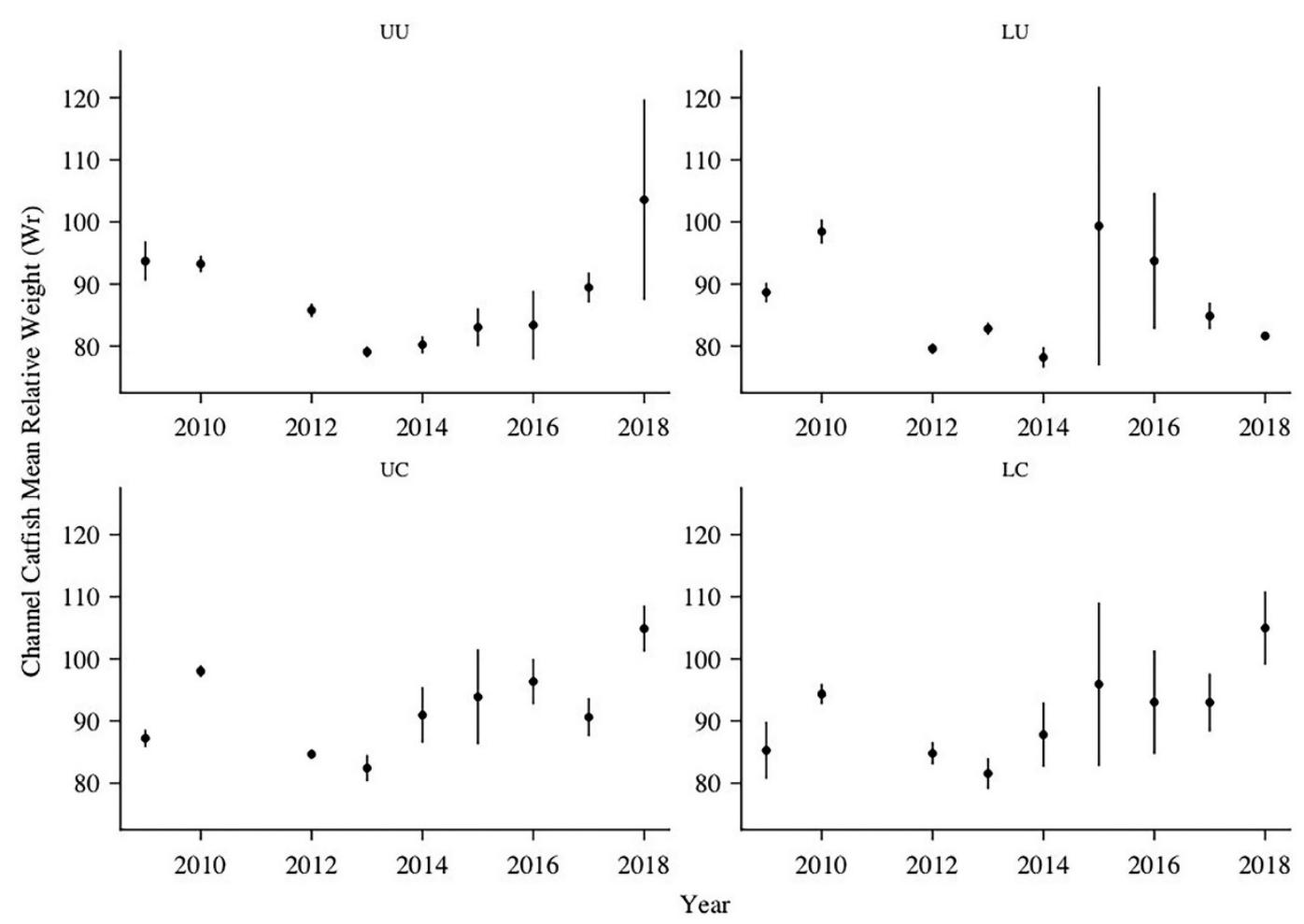

Figure 5. Mean relative weight ( $W_{r} ;$ with $95 \%$ confidence interval) of Channel Catfish collected from standardized assessments conducted during 2009-2018 in four segments of the Missouri River: upper unchannelized (UU), lower unchannelized (LU), upper channelized (UC), and lower channelized (LC). 

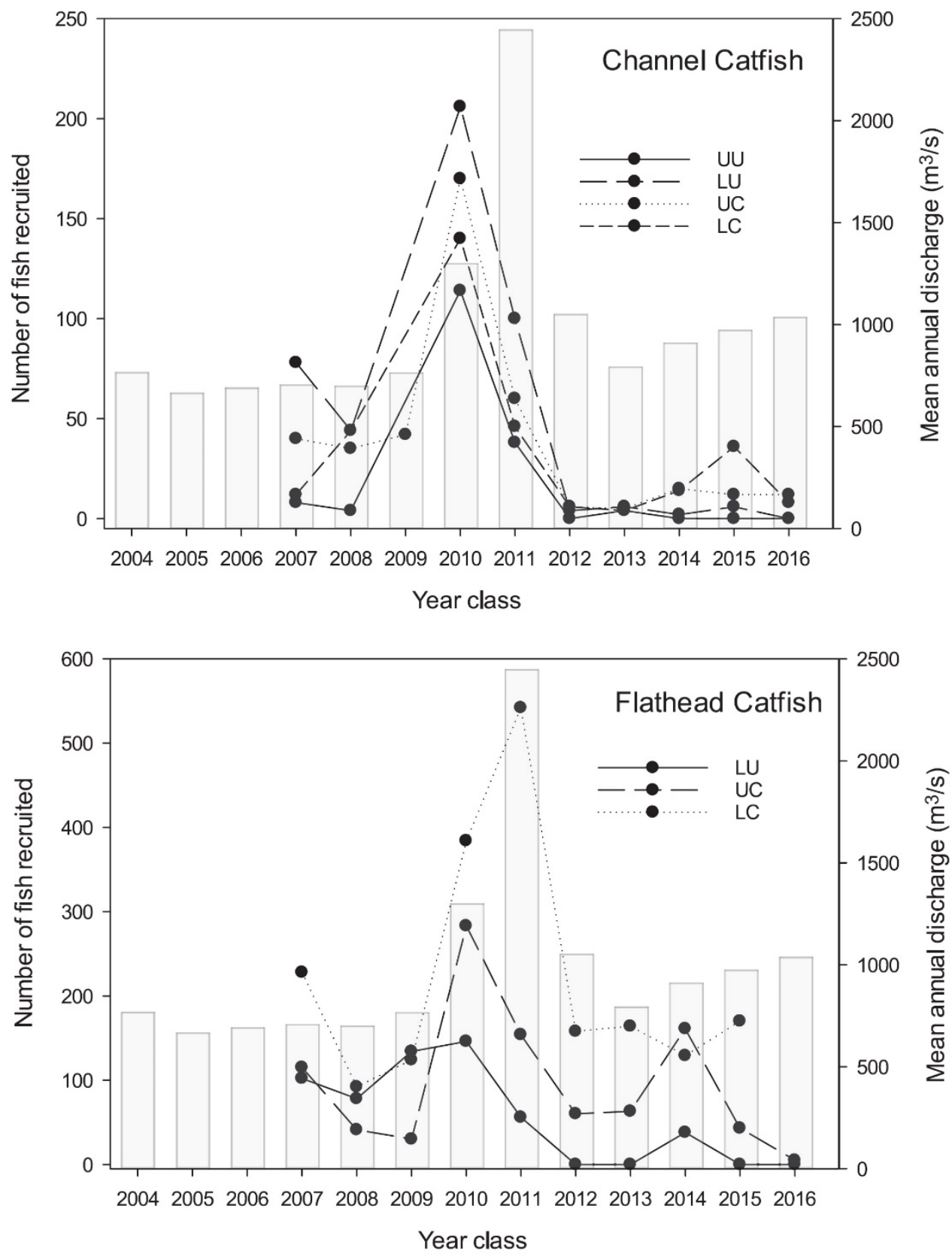

Figure 6. Recruitment of Channel Catfish (top panel) and Flathead Catfish (bottom panel) from fish collected within four segments of the Missouri River: upper unchannelized (UU), lower unchannelized (LU), upper channelized (UC), and lower channelized (LC). The number of fish in each year-class was determined by back-calculating age-2 individuals collected in each year of sampling. Mean annual discharge $\left(\mathrm{m}^{3} / \mathrm{s}\right.$; bars) is reported for the U.S. Geological Survey's Omaha, Nebraska, gauge (06610000) as a reference for general water conditions in each year. Data were not available for the 2016 Flathead Catfish year-class in the LC segment. 


\section{Flathead Catfish}

Flathead Catfish $(N=13,304)$ relative abundance differed among the river segments when all years were combined ( $\chi 2=89.14, \mathrm{df}=3, P<0.0001$; Figure 7). Pairwise comparisons indicated no differences in Flathead Catfish relative abundance between the upper and lower channelized segments $(P=0.476)$; however, both channelized segments had higher relative abundances than the unchannelized segments $(P<0.001)$. Few Flathead Catfish were found in the lower and upper unchannelized segments, and there were multiple years during which sampling in these segments resulted in zero catch of Flathead Catfish (Figure 7). A higher proportion of larger Flathead Catfish was found in the upper unchannelized Missouri River, albeit in low numbers (Figure 4). Flathead Catfish grew slower in the unchannelized segments. Mean annual growth increment at age 3 was significantly greater in the lower and upper channelized segments and the lower unchannelized segment $\left(F_{4,34}=8.483, P<0.0001\right.$; Table 1$)$. 

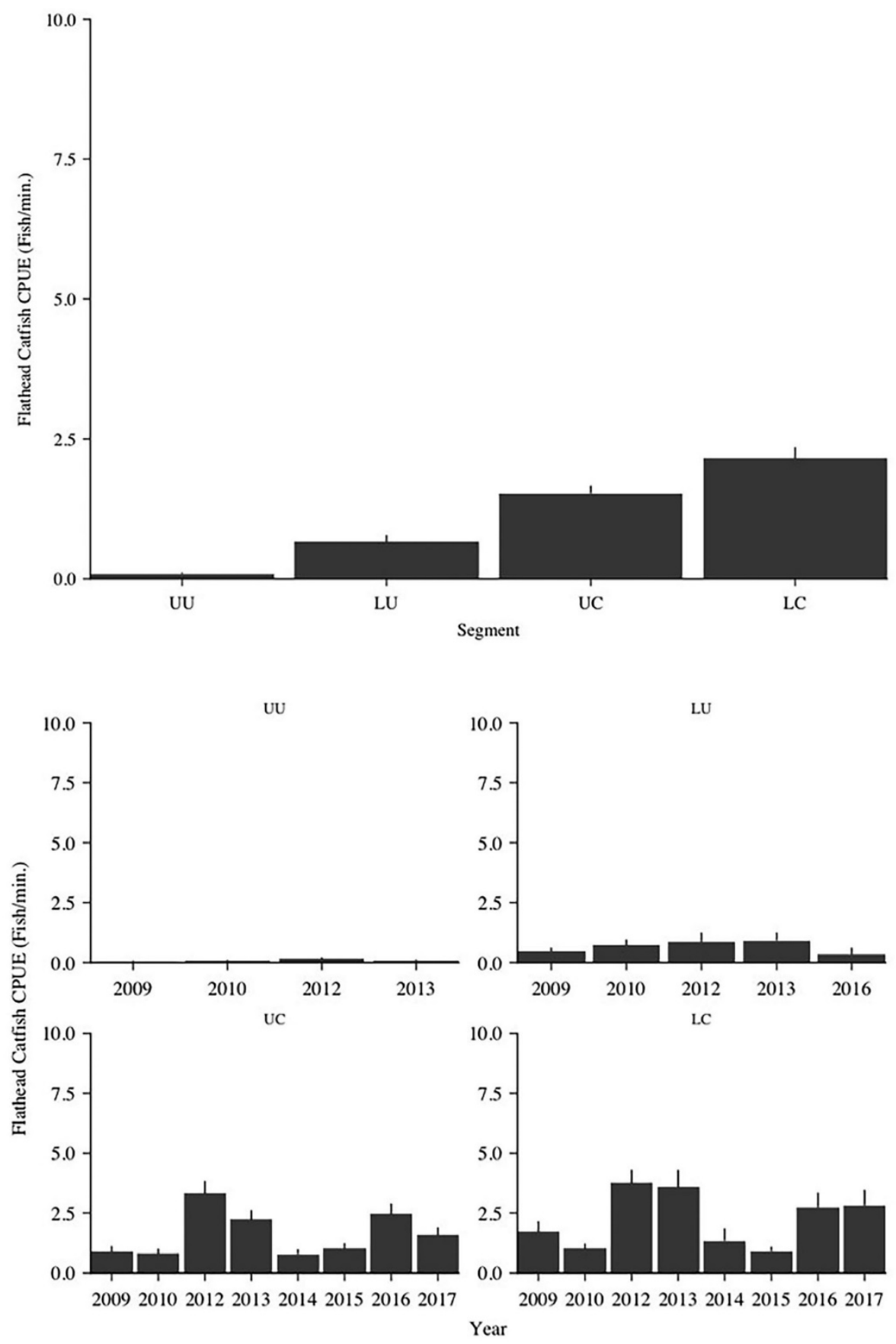

Figure 7. Flathead Catfish mean CPUE (fish/min of electrofishing; with $95 \%$ confidence interval) calculated from standardized assessments conducted during 2009-2017 in four segments of the Missouri River: upper unchannelized (UU), lower unchannelized (LU), upper channelized (UC), and lower channelized (LC). Top panel shows all years combined for each segment; bottom panel shows annual comparisons among segments. No sampling occurred in 2011. All other missing years represent zero fish captured. 
Flathead Catfish mean $W_{r}$ was similar between the lower and upper channelized segments (lower: $W_{r}\left[\right.$ mean \pm SE] $=95 \pm 0.16$; upper: $W_{r}=100 \pm 0.20$ ) and between the lower and upper unchannelized segments (lower: $W_{r}=99 \pm 12.64$; upper: $W_{r}=91 \pm 1.05$; Figure 8). The ANOVA model indicated no evidence for differences in $W_{r}$ among segments for Flathead Catfish $\left(F_{3,31}=1.839, P=0.1610\right)$. Total $Z$ differed among river segments for Flathead Catfish $\left(F_{3,28}=12.833, P<0.0001\right)$. Total $A$ was $53 \%$ in the lower channelized segment, $51 \%$ in the upper channelized segment, $43 \%$ in the lower unchannelized segment, and $62 \%$ in the upper unchannelized segment across years (Table 1). Recruitment of Flathead Catfish was more variable among segments than that of Channel Catfish. Recruitment in the lower channelized segment was mostly consistent outside of two large peaks that occurred during 2010 and 2011 (Figure 6). In the upper channelized segment, the largest peak occurred during 2010, with additional smaller peaks occurring in 2007, 2011, and 2014. Recruitment was generally lower in the lower unchannelized segment. Consistent recruitment occurred in every year prior to 2011 but dropped to negligible detection of Flathead Catfish in subsequent years.

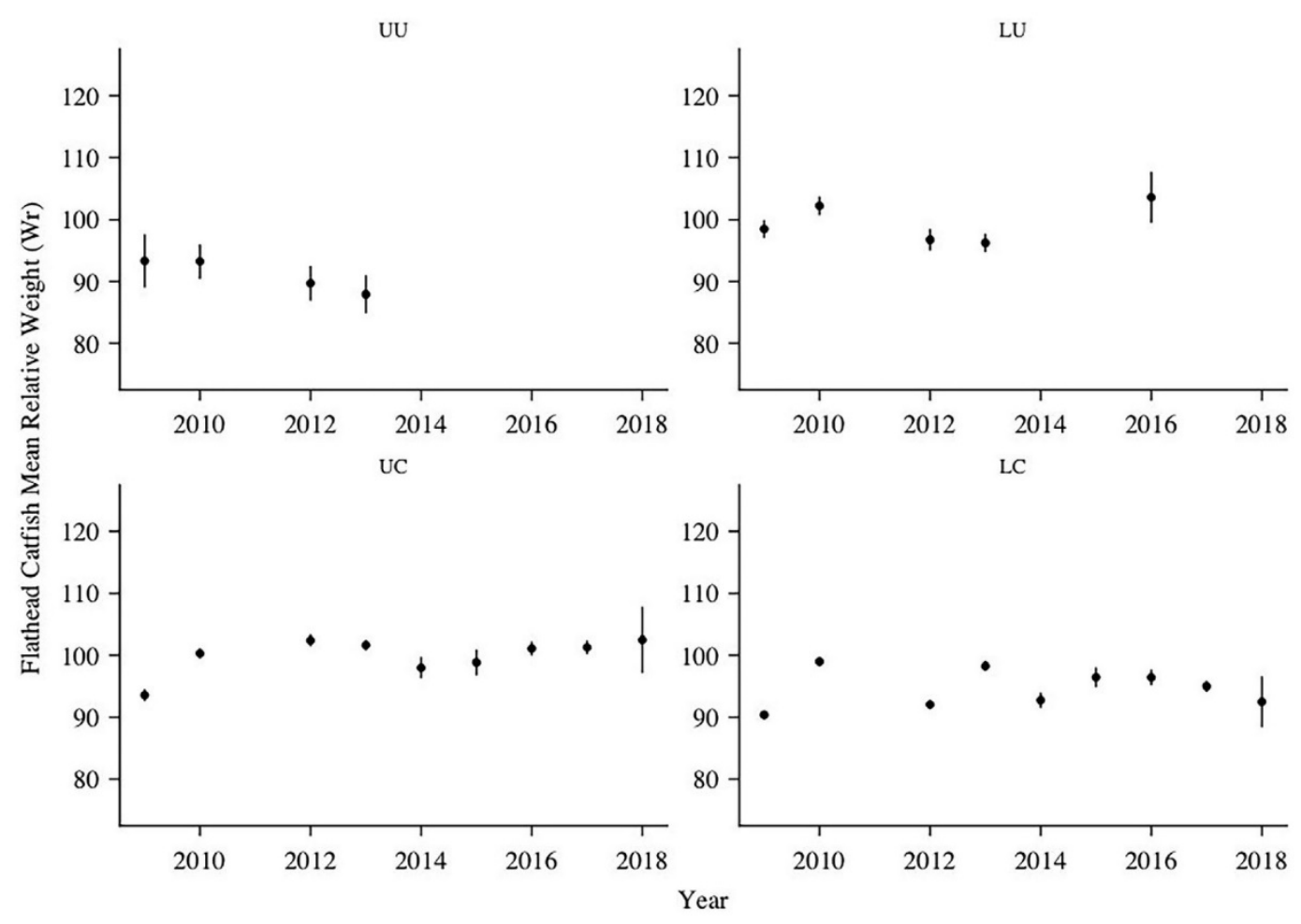

Figure 8. Mean relative weight ( $W_{r}$; with $95 \%$ confidence interval) of Flathead Catfish collected from standardized assessments conducted during 2009-2018 in four segments of the Missouri River: upper unchannelized (UU), lower unchannelized (LU), upper channelized (UC), and lower channelized (LC). No sampling occurred in 2011. All other missing years represent zero fish captured. 


\section{Discussion}

Catfish population characteristics differed among the four Missouri River segments that we examined. Each species of catfish displayed unique demographics and dynamics within segments, relating to environmental changes and habitat characteristics. Previous work has suggested that catfish populations respond to environmental changes, including habitat alteration along a river's length (Paukert and Makinster 2009; Hogan 2011). Varying types of anthropogenic modifications have created unique habitat conditions between the unchannelized and channelized portions of the Missouri River. The addition of extensive rock habitat from the channelization process has likely provided ideal habitat for catfishes. Large numbers of Flathead Catfish are often seen within the rock habitat on outer banks and on wing-dike habitats. Interestingly, Flathead Catfish relative abundance was much lower in the unchannelized segments, which were largely devoid of rock revetment along the banks.

Channelization of the Missouri River has created an inhospitable environment for many species. Since modification of the river, water velocity has significantly increased and variability in flow has decreased (Pegg et al. 2003). Large-scale declines in native species, including the endangered Pallid Sturgeon Scaphirhynchus albus, have been linked to these habitat modifications (Jacobson and Galat 2008; Jordan et al. 2016). Channelization alone does not appear to influence the relative abundances of Channel Catfish and Flathead Catfish. For example, the highest and lowest relative abundances for Channel Catfish occurred in the upper and lower channelized segments, and Flathead Catfish relative abundance was highest in both of the channelized segments. However, there was evidence to suggest that environmental characteristics were influencing other dynamic rate functions, such as growth and mortality. Subadult growth rates for both catfish species were greater in channelized segments. Channel Catfish mortality was highest in channelized segments, which was consistent with the maximum ages found in the channelized (age 9) and unchannelized (age 15) segments.

Flathead Catfish size structure and mortality should be interpreted with caution. Large adults were often seen during electrofishing efforts but were difficult to collect, despite our use of a chase boat to increase catch. The absence of large, old individuals may have inflated mortality estimates, particularly in the upper unchannelized segment, where slowergrowing and older fish occur. The inability to remove pectoral spines from large fish (> 800 $\mathrm{mm}$ ) also may have inflated mortality estimates; however, only a small proportion of fish was collected in this size range ( $n=65 ;<1 \%$ of Flathead Catfish sampled). An additional caveat is that pectoral spines have been shown to be less accurate and precise than sagittal otoliths for Channel Catfish, especially those that are older than age 4 (Buckmeier et al. 2002). However, accuracy of pectoral spines for young fish was greater than $90 \%$ (Buckmeier et al. 2002) and estimates of population demographics from both structures (i.e., otoliths and spines) were shown to provide similar results (Colombo et al. 2010). Comparative work with known-age individuals is not available for Flathead Catfish, but assessments of reader precision between sagittal otoliths and pectoral spines have indicated that spines may underestimate age compared to otoliths (Nash and Irwin 1999; Olive et al. 2011). 
High-flow events, such as those seen in 2010 and 2011, appear to have been important drivers in catfish recruitment. High flow in 2010 resulted in floodplain inundation throughout most of the lower Missouri River, leading to high recruitment. The large-scale flood event that occurred in 2011 was unprecedented. Discharge of the Missouri River allowed substantial (and prolonged) floodplain connectivity. Total catch of Channel Catfish increased in the years immediately after the 2010 and 2011 flood events. However, relative abundance declined in subsequent years to the lowest catch rates recorded in our study period. Flathead Catfish similarly displayed declines in relative abundance during the 3-4 years after 2011. The direct mechanisms for declines in catch rates after the flood are unknown; however, other species displayed similar results. For example, Pallid Sturgeon catch was reduced and fish displayed poor condition in the years after 2011 (Steffensen and Mestl 2016). In addition, small-bodied fishes were greatly reduced post-2011, particularly in the upper channelized segment (Huenemann and Steffensen 2019).

The importance of floodplain connectivity cannot be understated, as it serves as a foundation for understanding how lotic systems function (e.g., Vannote et al. 1980; Junk et al. 1989). However, highly modified systems can create situations that may result in unpredictable consequences. For example, Hogberg et al. (2016) found that low-flow conditions in the channelized Missouri River resulted in the best growth of age-0 Channel Catfish because low-flow periods were presumably the only times when shallow and low-velocity habitat existed. High-flow events that occurred in 2010 and 2011 provided results consistent with the river function literature, where floodplain connectivity showed immediate positive impacts. In contrast to predictable river function, the fish community in subsequent years was negatively impacted - an unpredictable lag effect. Though a flood similar in magnitude to the 2011 event is not a typical occurrence, climate change may create more regular occurrences of extreme climatic events (e.g., Swanston et al. 2018). For example, in 2019 the Missouri River again flooded and surpassed gauge height level records that were set in 2011. Impacts of this flood on the fish community have not yet been assessed or realized, but it illustrates the importance of understanding how extreme climatic conditions may impact fishes such as catfish in the future.

Managing catfish in a large-river system is challenging in that fish can make long migrations and cross interjurisdictional boundaries, and they are subjected to large fluctuations in environmental conditions. Adding complexities, such as human-induced changes, can further complicate how fish inhabit these systems. Managers thus have to be aware of not only the spatial requirements for these fish but also how abiotic and biotic factors impact populations. In this study, Channel Catfish and Flathead Catfish in the Missouri River displayed unique demographics and dynamics among spatially distinct areas resulting from varying levels of anthropogenic modification. Effectively managing populations of these species may require reach-specific regulations. For example, having a more restrictive Channel Catfish regulation in the lower channelized segment to enhance size structure may not achieve the desired results because of high mortality rates and reduced longevity. Similarly, the Missouri River traverses several states throughout our study area, and cohesive management of shared resources would be necessary to achieve desired outcomes.

Our study illustrates how varying levels of human modification to a large-river system and extreme climatological events may impact or structure catfish populations. These data 
provide a basis for assessing catfish throughout this system and offer insight into how catfish populations in other large-river systems might function. Although we emphasize how this information is important for making management decisions, it also supports an adaptive management strategy wherein regulations can be adjusted when large-scale changes occur. Catfishes largely exhibit an equilibrium life history strategy that is favorable under uniform conditions (Winemiller and Rose 1992). Relative abundance dropped significantly after the 2011 flood, and numbers had not fully rebounded to pre-flood levels in the 7 years since that event. If extreme hydrological events, such as those in 2011 and 2019, continue to occur at more frequent intervals, catfish populations may deteriorate.

Ackknowledgments - We thank the numerous graduate students and technicians that spent many hours conducting field and laboratory work associated with this project. Specifically, D. Turner, Z. Horstman, S. Siddons, N. Hogberg, C. Goble, and A. Blank were invaluable throughout the study. Funding was provided by the Federal Aid in Sport Fish Restoration Program (F-75-R) to the Nebraska Game and Parks Commission and the School of Natural Resources, University of Nebraska-Lincoln. There is no conflict of interest declared in this article.

\section{References}

Bodine, K. A., D. E. Shoup, J. Olive, Z. L. Ford, R. Krogman, and T. J. Stubbs. 2013. Catfish sampling techniques: where we are now and where we should go. Fisheries 38:529-546.

Buckmeier, D. L., E. R. Irwin, R. K. Betsill, and J. A. Prentice. 2002. Validity of otoliths and pectoral spines for estimating ages of Channel Catfish. North American Journal of Fisheries Management 22:934-942.

Buckmeier, D. L., and J. W. Schlechte. 2009. Capture efficiency and size selectivity of Channel Catfish and Blue Catfish sampling gears. North American Journal of Fisheries Management 29:404-416.

Bunn, S. E., and A. H. Arthington. 2002. Basic principles and ecological consequences of altered flow regimes for aquatic biodiversity. Environmental Management 30:492-507.

Colombo, R. E., Q. E. Phelps, C. M. Miller, J. E. Garvey, R. C. Heidinger, and N. S. Richards. 2010. Comparison of Channel Catfish age estimates and resulting population demographics using two common structures. North American Journal of Fisheries Management 30:305-308.

Dynesius, M., and C. Nilsson. 1994. Fragmentation and flow regulation of river systems in the northern third of the world. Science 266:753-762.

Funk, J. L., and J. W. Robinson. 1974. Changes in the channel of the lower Missouri River and effects on fish and wildlife. Missouri Department of Conservation, Aquatic Series 11, Jefferson City.

Galat, D., C. Berry, W. Gardner, J. Hendrickson, G. Mestl, G. Power, C. Stone, and M. Winston. 2005. Spatiotemporal patterns and changes in Missouri River fishes. Pages 249-291 in J. N. Rinne, R. M. Hughes, and B. Calamusso, editors. Historical changes in large river fish assemblages of the Americas. American Fisheries Society, Bethesda, Maryland.

Hesse, L. W., and W. Sheets. 1993. The Missouri River hydrosystem. Fisheries 18(5):5-14.

Hogan, Z. S. 2011. Ecology and conservation of large-bodied freshwater catfish: a global perspective. Pages 39-53 in P. H. Michaletz and V. H. Travnichek, editors. Conservation, ecology, and management of catfish: the second international symposium. American Fisheries Society, Symposium 77, Bethesda, Maryland. 
Hogberg, N. P., M. J. Hamel, and M. A. Pegg. 2016. Age-0 Channel Catfish Ictalurus punctatus growth related to environmental conditions in the channelized Missouri River, Nebraska. River Research and Applications 32:744-752.

Huenemann, T. W., and K. D. Steffensen. 2019. 2018 annual report: Pallid Sturgeon population assessment project and associated fish community monitoring for the Missouri River: segment 8 . Nebraska Game and Parks Commission, Lincoln.

Jacobson, R. B., and D. L. Galat. 2008. Design of a naturalized flow regime-an example from the lower Missouri River, USA. Ecohydrology 1:81-104.

Jordan, G. R., E. J. Heist, P. J. Braaten, A. J. DeLonay, P. Hartfield, D. P. Herzog, K. M. Kappenman, and M. A. H. Webb. 2016. Status of knowledge of the Pallid Sturgeon (Scaphirhynchus albus Forbes and Richardson, 1905). Journal of Applied Ichthyology 32(S1):191-207.

Junk, W. J., P. B. Bayley, and R. E. Sparks. 1989. The flood pulse concept in river-floodplain systems. Canadian Special Publication of Fisheries and Aquatic Sciences 106:110-127.

Koch, J. D., and M. C. Quist. 2007. A technique for preparing fin rays and spines for age and growth analysis. North American Journal of Fisheries Management 27:782-784.

Maceina, M. J., and P. W. Bettoli. 1998. Variation in Largemouth Bass recruitment in four mainstream impoundments of the Tennessee River. North American Journal of Fisheries Management 18: 998-1003.

McManamay, R. A., and E. A. Frimpong. 2015. Hydrologic filtering of fish life history strategies across the United States: implications for stream flow alteration. Ecological Applications 25:243-263.

Mims, M. C., and J. D. Olden. 2013. Fish assemblages respond to altered flow regime via ecological filtering of life history strategies. Freshwater Biology 58:50-62.

Nash, M. K., and E. R. Irwin. 1999. Use of otoliths versus pectoral spines for aging adult Flathead Catfish. Pages 309-316 in E. R. Irwin, W. A. Hubert, C. F. Rabeni, H. L. Schramm, and T. Coon, editors. Catfish 2000: proceedings of the international ictalurid symposium. American Fisheries Society, Symposium 24, Bethesda, Maryland.

Ogle, D. H., P. Wheeler, and A. Dinno. 2020. FSA: fisheries stock analysis version 0.8.30.9000. Available: https://github.com/droglenc/FSA. (January 2002).

Olive, J., H. L. Schramm Jr., P. D. Gerard, and E. Irwin. 2011. An evaluation of agreement between pectoral spines and otoliths for estimating ages of catfishes. Pages 679-688 in P. H. Michaletz and V. H. Travnichek, editors. Conservation, ecology, and management of catfish: the second international symposium. American Fisheries Society, Bethesda, Maryland.

Paukert, C. P., and A. S. Makinster. 2009. Longitudinal patterns in Flathead Catfish relative abundance and length at age within a river: effects of an urban gradient. River Research and Applications 25:861-873.

Pegg, M. A., C. L. Pierce, and A. Roy. 2003. Hydrological alteration along the Missouri River basin: a time series approach. Aquatic Sciences 65:63-72.

Pope, K., and C. Kruse. 2007. Condition. Pages 423-472 in C. S. Guy and M. L. Brown, editors. Analysis and interpretation of freshwater fisheries data. American Fisheries Society, Bethesda, Maryland.

Pritt, J. J., M. R. DuFour, C. M. Mayer, E. F. Roseman, and R. L. DeBruyne. 2014. Sampling little fish in big rivers: larval fish detection probabilities in two Lake Erie tributaries and implications for sampling effort and abundance indices. Transactions of the American Fisheries Society 143:10111027.

R Core Team. 2019. R: a language and computing environment for statistical computing. R Foundation for Statistical Computing, Vienna. 
Steffensen, K. D., and G. E. Mestl. 2016. Assessment of Pallid Sturgeon relative condition in the upper channelized Missouri River. Journal of Freshwater Ecology 31:583-595.

Swanston, C., L. A. Brandt, M. K. Janowiak, S. D. Handler, P. Butler-Leopold, L. Iverson, F. R. Thompson III, T. A. Ontl, and P. D. Shannon. 2018. Vulnerability of forests of the Midwest and Northeast United States to climate change. Climatic Change 146:103-116.

Vannote, R. L., G. W. Minshall, K. W. Cummins, J. R. Sedell, and C. E. Cushing. 1980. The river continuum concept. Canadian Journal of Fisheries and Aquatic Sciences 37:130-137.

Vokoun, J. C., and C. F. Rabeni. 2001. A standardized sampling protocol for Channel Catfish in prairie streams. North American Journal of Fisheries Management 21:188-197.

Winemiller, K. O., and K. A. Rose. 1992. Patterns of life-history diversification in North American fishes: implications for population regulation. Canadian Journal of Fisheries and Aquatic Sciences 49:2196-2218.

Yager, L. A., M. D. Dixon, T. C. Cowman, and D. A. Soluk. 2013. Historic changes (1941-2008) in side channel and backwater habitats on an unchannelized reach of the Missouri River. River Research and Applications 29:493-501. 